\title{
Data report: volcanic glass shards from the Eocene-Oligocene transition interval at Site U1333'
}

\author{
Junichiro Kuroda ${ }^{2}$ and Thomas Westerhold ${ }^{3}$
}

\begin{abstract}
Chapter contents
Abstract.....................

Introduction ....................

Samples and methods................

Results and discussions .............

Conclusions...................... 3

Acknowledgments..................

References.................

Figure...................

Tables..................... 6
\end{abstract}

${ }^{1}$ Kuroda, J., and Westerhold, T., 2013. Data report: volcanic glass shards from the Eocene-Oligocene transition interval at Site U1333. In Pälike, H., Lyle, M., Nishi, H., Raffi, I., Gamage, K., Klaus, A., and the Expedition 320/321 Scientists, Proc. IODP, 320/ 321: Tokyo (Integrated Ocean Drilling Program Management International, Inc.).

doi:10.2204/iodp.proc.320321.211.2013

${ }^{2}$ Institute for Research on Earth Evolution, Japan

Agency for Marine-Earth Science and Technology,

2-15 Natsushima-cho, Yokosuka, Kanagawa 237-

0061, Japan. kurodaj@jamstec.go.jp

${ }^{3}$ MARUM-Center for Marine Environmental Sciences, University of Bremen, Klagenfurter Strasse, 28359 Bremen, Germany.

\begin{abstract}
We separated volcanic glasses from the Eocene-Oligocene transition interval at Integrated Ocean Drilling Program Site U1333, drilled during Expedition 320. Among 23 sediment samples we found five samples that contain volcanic glasses: one from Eocene radiolarian ooze and the others from Oligocene calcareous ooze. Glass shards were separated by handpicking from coarse sediment fractions ( $>75 \mu \mathrm{m}$ in size), which are composed mainly of microfossil fragments (radiolarians and foraminifers). Volcanic glasses from these five samples are dominated by clear silicic glass shards $80-300 \mu \mathrm{m}$ in size, but we cannot find other minerals such as quartz and feldspars or shards of brownish glass of dacitic composition. The glass shards are classified into three types based on their morphology: (1) flat to weakly concave (concoidal) shards without junctions (plate-type), (2) shards forming elongated fibrous to tubular vesicle walls (tube-type), and (3) fragments of globular bubbles (balloon-type). Electron microprobe analyses of 181 glass shards from interval 320-U1333C-14H-6W, 92-94 cm, revealed that the glass shards have uniform rhyolitic compositions relatively rich in alkaline elements ( $\mathrm{Na}$ and $\mathrm{K}$ ) but depleted in $\mathrm{Fe}, \mathrm{Mg}$, and $\mathrm{Ca}$. These results suggest that the origin of these glass shards was explosive silicic volcanos with either a single source or a mixture of multiple sources with similar compositions. The five samples that contain volcanic glasses suggest episodic explosive volcanic eruptions at this time. Given the rhyolitic compositions and proximity of Site U1333 to Central America, we regard Central American arc volcanism as the most likely source of the glass shards found at Site U1333.
\end{abstract}

\section{Introduction}

Integrated Ocean Drilling Program (IODP) Expedition 320/321 recovered sediment cores from eight sites in the eastern equatorial Pacific (see the "Expedition 320/321 summary" chapter [Pälike et al., 2010]). Sediment in a transition interval from late Eocene to early Oligocene was recovered at four sites, U1331-U1334, that commonly show an abrupt change in lithology from siliceous microfossil-rich Eocene sediment (typically radiolarian ooze) to calcareous microfossil-rich Oligocene sediment (typically nannofossil ooze). 
In this study we report volcanic glass shards separated from a sediment interval across the EoceneOligocene transition at Site U1333. We also measured major element compositions of volcanic glass shards by an element microprobe analyzer (EPMA). Based on morphological and chemical data, together with paleogeographical information, we discuss the potential source(s) of these glass shards.

\section{Samples and methods}

Twenty-three samples were taken from sediment cores at Site U1333 (Table T1). After removing the surface part, which might be contaminated, these samples were freeze-dried for $>24 \mathrm{~h}$. The coarse fraction of sediment was separated from $\sim 10 \mathrm{~g}$ of sediment with a $75 \mu \mathrm{m}$ sieve and subsequently dried in an oven overnight. Microscopic observation revealed that the coarse fraction of sediment samples is dominated by microfossil fragments such as radiolarians and foraminifers with trace fish teeth. We found five samples that contain volcanic glass shards (i.e., Samples 320-U1333A-10H-4W, 22-24 cm, 11X-2W, 22$24 \mathrm{~cm}$, and $12 \mathrm{X}-4 \mathrm{~W}, 22-24 \mathrm{~cm} ; 320-\mathrm{U} 1333 \mathrm{~B}-11 \mathrm{H}-$ $5 \mathrm{~W}, 81-83 \mathrm{~cm}$; and 320-U1333C-14H-6W, 92-94 $\mathrm{cm})$. Volcanic glass shards were further separated from the coarse fraction of samples by handpicking under a stereoscopic microscope. These glass shards were then washed with deionized water and dried again.

In preparation for electron microprobe analysis, glass shards were mounted in epoxy resin. The surface of samples in the resin was polished as flat and smooth as possible (using $1 \mu \mathrm{m}$ diamond paste) to avoid any influence from surface relief. The polished thin sections were cleaned in an ultrasonic cleaner and then coated with a $\sim 20 \mathrm{~nm}$ carbon layer to counteract sample charging. Major element compositions were measured with a JEOL JXA-8900RL EPMA at the Japan Agency for Marine Science and Technology (JAMSTEC). Concentrations of elements such as $\mathrm{Na}$, $\mathrm{Mg}, \mathrm{Al}, \mathrm{Si}, \mathrm{K}, \mathrm{Ca}, \mathrm{Ti}, \mathrm{Mn}$, and $\mathrm{Fe}$ were measured by wavelength-dispersive spectrometry (WDS). Measurements were performed under conditions of 15 $\mathrm{kV}$ accelerating voltage, $20 \mathrm{nA}$ specimen current, and $10 \mu \mathrm{m}$ beam diameter. Synthetic and mineral materials supplied by JEOL were used as analytical standards. Matrix effects such as absorption or fluorescence influences by surrounding elements were corrected using the conventional ZAF method (e.g., Philibert, 1963; Dumcumb and Reed, 1968). We confirmed that the decrease in the $\mathrm{Na}-\mathrm{K} \alpha$ line due to electron scattering was insignificant. Analytical precisions $(2 \sigma)$ based on the triplicate analyses of an inhouse glass standard were $<2 \%$ for $\mathrm{Al}, \mathrm{Si}, \mathrm{Mg}$, and $\mathrm{Ca}$;
$<4 \%$ for $\mathrm{Na}, \mathrm{Ti}$, and $\mathrm{Fe}$; and $~ 25 \%$ for $\mathrm{K}$ and $\mathrm{Mn}$. Differences between our results of the in-house glass standard and those of reference values measured with the FE-EPMA JXA-8800F at JAMSTEC (H. Shukuno, pers. comm., 2011) were $<1 \%$ for $\mathrm{Mg}$, Si, and $\mathrm{Fe} ;<3 \%$ for $\mathrm{Al}, \mathrm{Ca}$, and $\mathrm{Ti} ; \sim 6 \%$ for $\mathrm{Na}$ and $\mathrm{K}$; and $\sim 27 \%$ for $\mathrm{Mn}$. The large errors for $\mathrm{Mn}$ and $\mathrm{K}$ are attributed to very low concentrations for these elements $(<0.2 \%)$.

\section{Results and discussions}

We used depth scales compiled by Westerhold et al. (2012): meters below seafloor (mbsf or core depth below seafloor, method A [CSF-A]) is the core depth below seafloor, actual length of the recovered core, and the drillers depth; revised meters composite depth (rmcd or revised core composite depth below seafloor, method A [CCSF-A]) is the new revised depth scale of the spliced section. In addition, the depth scale of Site U1333 cores are correlated to the corrected revised meters composite depth of Ocean Drilling Program (ODP) Site 1218. Sediment in the Eocene-Oligocene transition shows a clear lithologic change from dark-color radiolarian ooze in the upper Eocene interval to light-color calcareous/nannofossil ooze in the overlying lower Oligocene interval (see the "Site U1333" chapter [Expedition 320/321 Scientists, 2010]). We found that five samples contained volcanic glasses in the coarse fraction of sediments ( $>75 \mu \mathrm{m}$ in size) (Table T1): four white nannofossil ooze samples from the lower Oligocene interval and one very pale brown calcareous radiolarian ooze sample from the uppermost Eocene. Volcanic glasses from these five samples are dominated by clear silicic glass shards $80-300 \mu \mathrm{m}$ in size (Fig. F1). We cannot find other minerals such as quartz, feldspar, mica, hornblende, or pyroxene. Brownish glass shards that indicate dacitic composition were rarely observed (e.g., Sample 320-U1333A-11X-2W, 22-24 $\mathrm{cm})$. The glass shards are classified into three types based on their morphology (e.g., Heiken, 1972; Furusawa, 1995, and references therein): flat to weakly concave (concoidal) shards without junctions (platetype), shards forming elongated fibrous to tubular vesicle walls (tube-type), and fragments of globular bubbles (balloon-type) (Fig. F1). Both tube- and balloon-type glass shards show various fracture surfaces including T- and Y-shape sections. Vesicle walls are smooth, and alteration and argillation appear to be insignificant.

Electron microprobe analyses of 181 glass shards from Sample 320-U1333C-14H-6W, 92-94 cm, revealed that the glass shards have uniform rhyolitic compositions $\left(\mathrm{SiO}_{2}=73.4 \pm 0.4 \mathrm{wt} \% ; \mathrm{Al}_{2} \mathrm{O}_{3}=11.5 \pm\right.$ 
$0.1 \mathrm{wt} \%)$ enriched in alkaline elements $\left(\mathrm{Na}_{2} \mathrm{O}=3.02\right.$ $\pm 0.20 \mathrm{wt} \% ; \mathrm{K}_{2} \mathrm{O}=5.27 \pm 0.22 \mathrm{wt} \%$ ) but depleted in $\mathrm{Fe}, \mathrm{Mg}$, and $\mathrm{Ca}\left(\mathrm{FeO}^{*}=0.66 \pm 0.09 \mathrm{wt} \% ; \mathrm{MgO}=0.05\right.$ $\pm 0.02 \mathrm{wt} \% ; \mathrm{CaO}=0.40 \pm 0.07 \mathrm{wt} \%$ ) (Table T2). The uniform major element compositions of the volcanic glasses indicate either a single source or a mixture of multiple sources with similar compositions. Chemical composition and morphology suggest that the origin of these glass shards was explosive volcanism(s) of rhyolitic composition. The five sediment samples that contain volcanic glass shards show no clear correlation with magnetic susceptibility (Fig. F1), but these samples seem to coincide with potassium peaks taken by a high-resolution X-ray fluorescence core scanner (Westerhold et al., 2012; T. Westerhold et al., pers. comm., 2012)

An episode of enhanced silicic volcanism in Central America that began in the middle Eocene and terminated around the Eocene/Oligocene boundary has been reported at ODP Site 999 in Caribbean Kogi Rise (Shipboard Science Party, 1997). Scientists at the site interpreted the Eocene volcanic episode as probably ignimbrite-forming eruptions on the Chortis Block in the Central American arc. The initiation of the Eocene volcanic episode may be related to plate tectonic rearrangements in the Pacific Ocean due to the abrupt change in the direction of Pacific plate motion at $43 \mathrm{Ma}$ to a more western direction as recorded by the bend in the Hawaiian hotspot chain, which is likely to have had effects on the relative motion of the opposing Farallon plate and thus on subduction in the Middle America Trench. Our results from the eastern equatorial Pacific (Site U1333) indicate that the volcanism started around the Eocene/Oligocene boundary and then lasted after the Eocene-Oligocene transition. We need further investigation to clarify whether the Oligocene volcanic glasses from Site U1333 indicate that the enhanced Eocene eruption episode lasted after the Eocene/Oligocene boundary.

\section{Conclusions}

We report morphology and major element compositions of volcanic glasses separated from a from the Eocene-Oligocene transition interval at Site U1333. Among 23 sediment samples, we found five samples containing volcanic glass shards: one from uppermost Eocene radiolarian ooze and the others from lower Oligocene white calcareous oozes. Volcanic glasses from these samples are dominated by clear silicic glass shards $80-300 \mu \mathrm{m}$ in size, and they are classified into plate-type, tube-type, and balloontype based on their morphology. Vesicle walls are smooth, and no clear evidence of argillation was found. Electron microprobe analyses of 181 glass shards from Sample 320-U1333C-14H-6W, 92-94 $\mathrm{cm}$, revealed that the glass shards have uniform rhyolitic compositions relatively rich in alkaline elements ( $\mathrm{Na}$ and $\mathrm{K}$ ) but depleted in $\mathrm{Fe}, \mathrm{Mg}$, and $\mathrm{Ca}$. These results suggest that the origin of these glass shards was explosive silicic volcanos with either a single source or a mixture of multiple sources with similar compositions. The samples that contain volcanic glasses suggest episodic explosive volcanic eruptions at this time. Given the rhyolitic compositions and proximity of Site U1333 to Central America, we regard Central American arc volcanism as the most likely source of the glass shards found at Site U1333.

\section{Acknowledgments}

We thank Drs. K. Uematsu, T. Toyofuku, and H. Shukuno for their support on electron microprobe analyses. We also thank Y. Nakamura and Y. Otsuki for sample preparations. Samples and/or data were provided by IODP. Financial support for this research was provided by the Deutsche Forschungsgemeinschaft (DFG), Japan Drilling Earth Science Consortium (J-DESC), and Center for Deep Earth Exploration (CDEX), JAMSTEC.

\section{References}

Duncumb, P., and Reed, S.J.B., 1968. The calculation of stopping power and backscatter effects in electron probe microanalysis. In Heinrich, K.F.J. (Ed.), Quantitative Electron Probe Microanalysis. NBS Spec. Publ. (U. S.), 298:133-154.

Expedition 320/321 Scientists, 2010. Site U1333. In Pälike, H., Lyle, M., Nishi, H., Raffi, I., Gamage, K., Klaus, A., and the Expedition 320/321 Scientists, Proc. IODP, 320/ 321: Tokyo (Integrated Ocean Drilling Program Management International, Inc.). doi:10.2204/ iodp.proc.320321.105.2010

Furusawa, A., 1995. Identification of tephra based on statistical analysis of refractive index and morphological classification of volcanic glass shards. J. Geol. Soc. Jpn., 101(2):123-133. doi:10.5575/geosoc.101.123

Heiken, G., 1972. Morphology and petrology of volcanic ashes. Geol. Soc. Am. Bull., 83(7):1961-1987.

doi:10.1130/

0016-7606(1972)83[1961:MAPOVA]2.0.CO;2

Pälike, H., Nishi, H., Lyle, M., Raffi, I., Gamage, K., Klaus, A., and the Expedition 320/321 Scientists, 2010. Expedition 320/321 summary. In Pälike, H., Lyle, M., Nishi, H., Raffi, I., Gamage, K., Klaus, A., and the Expedition 320/ 321 Scientists, Proc. IODP, 320/321: Tokyo (Integrated Ocean Drilling Program Management International, Inc.). doi:10.2204/iodp.proc.320321.101.2010 
Philibert, J., 1963. A method of calculating the absorption correction in electron-probe microanalysis. In Pattee, H.H., Cosslett, V.E., and Engström, A. (Eds.), X-ray Optics and X-ray Microanalysis: New York (Academic Press), 379-392.

Shipboard Scientific Party, 1997. Caribbean volcanism, Cretaceous/Tertiary impact, and ocean-climate history: synthesis of Leg 165. In Sigurdsson, H., Leckie, R.M., Acton, G.D., et al., Proc. ODP, Init. Repts., 165: College Station, TX (Ocean Drilling Program), 377-400. doi:10.2973/odp.proc.ir.165.108.1997

Westerhold, T., Röhl, U., Wilkens, R., Pälike, H., Lyle, M., Jones, T.D., Bown, P., Moore, T., Kamikuri, S., Acton, G.,
Ohneiser, C., Yamamoto, Y., Richter, C., Fitch, P., Scher, H., Liebrand, D., and the Expedition 320/321 Scientists, 2012. Revised composite depth scales and integration of IODP Sites U1331-U1334 and ODP Sites 1218-1220. In Pälike, H., Lyle, M., Nishi, H., Raffi, I., Gamage, K., Klaus, A., and the Expedition 320/321 Scientists, Proc. IODP, 320/321: Tokyo (Integrated Ocean Drilling Program Management International, Inc.). doi:10.2204/ iodp.proc.320321.201.2012

Initial receipt: 28 June 2012

Acceptance: 17 October 2012

Publication: 18 January 2013

MS 320321-211 
Figure F1. Single polarized photomicrographs of glass shards separated from sediment samples (upper panels) and high-resolution depth profile of magnetic susceptibility in the Eocene-Oligocene transition interval (lower panel). The depth scale of the lower panel is the corrected revised meters composite depth (rmcd) of Site 1218 (Westerhold et al., 2012). B = balloon-type, $\mathrm{P}=$ plate-type, $\mathrm{T}=$ tube-type.

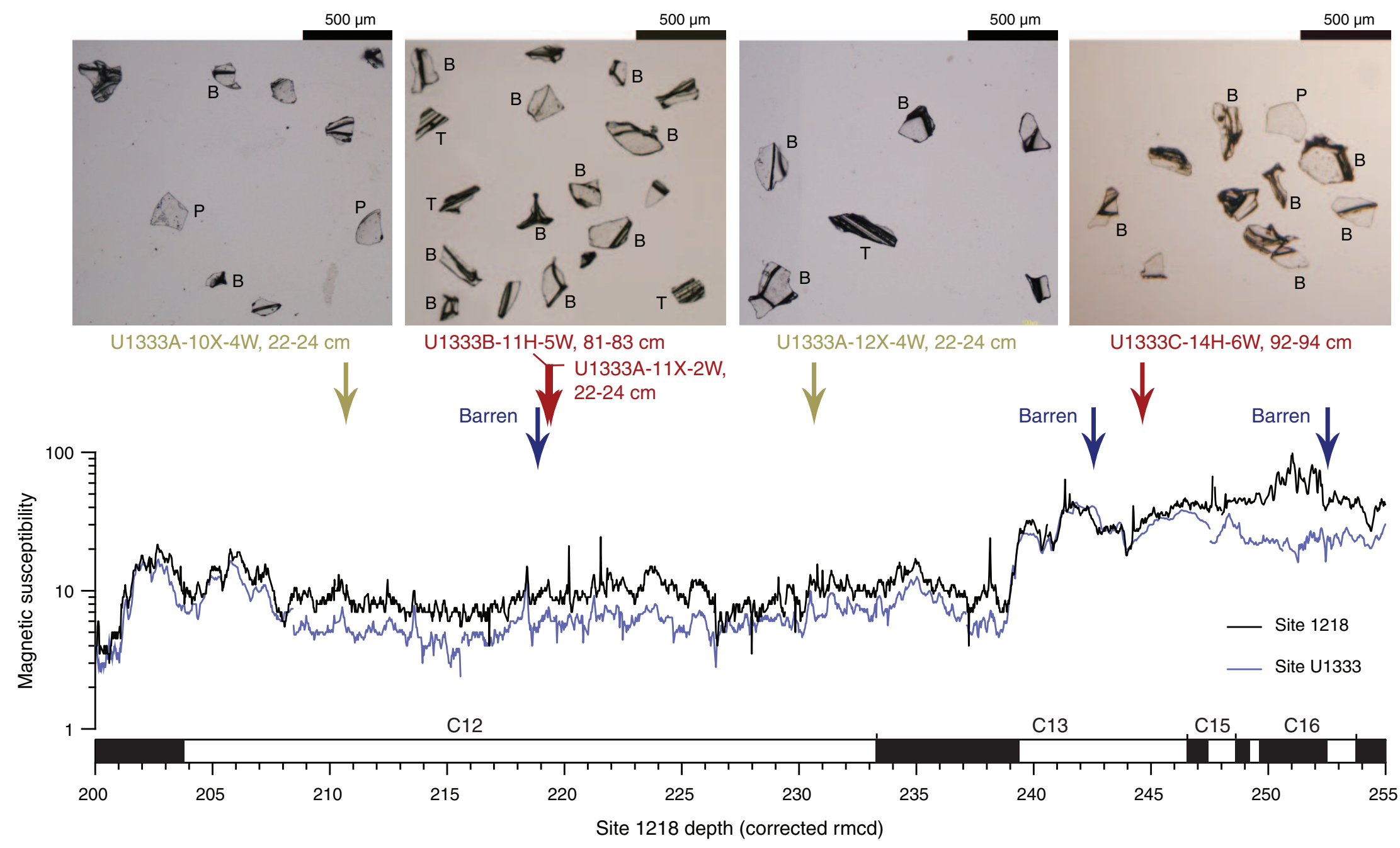


Table T1. Occurrences and abundances of volcanic glass shards from the Eocene-Oligocene transition interval at Site U1333.

\begin{tabular}{|c|c|c|c|c|c|c|c|}
\hline \multirow{3}{*}{$\begin{array}{l}\text { Core, section, } \\
\text { interval }(\mathrm{cm})\end{array}$} & \multicolumn{6}{|c|}{ Depth } & \multirow{3}{*}{$\begin{array}{c}\text { Occurrences and } \\
\text { abundances of glass } \\
\text { shards }\end{array}$} \\
\hline & \multicolumn{2}{|c|}{ mbsf (CSF-A) } & \multicolumn{2}{|c|}{$\begin{array}{c}\text { rmcd } \\
\text { (adjusted revised CCSF-A) }\end{array}$} & \multicolumn{2}{|c|}{ rmcd at Site 1218} & \\
\hline & Top & Bottom & Top & Bottom & Top & Bottom & \\
\hline \multicolumn{8}{|l|}{ 320-U1333A- } \\
\hline $1 \mathrm{H}-2 \mathrm{~W}, 22-24$ & 1.72 & 1.74 & 6.38 & 6.4 & 71.19 & 71.21 & Barren \\
\hline $8 \mathrm{H}-4 \mathrm{~W}, 22-24$ & 71.02 & 71.04 & 86.4 & 86.42 & 184.59 & 184.61 & Barren \\
\hline $9 \mathrm{H}-4 \mathrm{~W}, 22-24$ & 80.72 & 80.74 & 98.45 & 98.47 & 198.16 & 198.18 & Barren \\
\hline $10 \mathrm{H}-4 \mathrm{~W}, 22-24$ & 90.22 & 90.24 & 109.58 & 109.6 & 210.65 & 210.67 & Trace \\
\hline $11 X-2 W, 22-24$ & 96.72 & 96.74 & 117.44 & 117.46 & 219.37 & 219.39 & Abundant \\
\hline $12 X-4 W, 22-24$ & 105.42 & 105.44 & 127.3 & 127.32 & 230.54 & 230.56 & Few \\
\hline $13 X-3 W, 20-22$ & 113.5 & 113.52 & 136.55 & 136.57 & 242.6 & 242.62 & Barren \\
\hline $14 X-2 W, 24-26$ & 121.74 & 121.76 & 145.43 & 145.45 & 252.49 & 252.51 & Barren \\
\hline $14 X-4 W, 24-26$ & 124.74 & 124.76 & 148.04 & 148.06 & 254.57 & 254.59 & Barren \\
\hline $15 X-2 W, 25-27$ & 131.35 & 131.37 & 158.09 & 158.11 & 263.24 & 263.26 & Barren \\
\hline $15 X-4 W, 25-27$ & 134.35 & 134.37 & 161.16 & 161.18 & 265.24 & 265.26 & Barren \\
\hline $16 X-4 W, 23-25$ & 143.93 & 143.95 & 171.56 & 171.58 & 274.26 & 274.28 & Barren \\
\hline $17 X-4 W, 20-22$ & 153.5 & 153.52 & 183.08 & 183.1 & & & Barren \\
\hline $18 \mathrm{X}-2 \mathrm{~W}, 22-24$ & 160.12 & 160.14 & 187.02 & 187.04 & & & Barren \\
\hline $18 X-4 W, 22-24$ & 162.46 & 162.48 & 189.36 & 189.38 & & & Barren \\
\hline $19 X-2 W, 21-23$ & 169.71 & 169.73 & 195.46 & 195.48 & & & Barren \\
\hline $19 X-4 W, 21-23$ & 172.71 & 172.73 & 198.46 & 198.48 & & & Barren \\
\hline $20 X-2 W, 21-23$ & 179.31 & 179.33 & 205.06 & 205.08 & & & Barren \\
\hline \multicolumn{8}{|l|}{ 320-U1333B- } \\
\hline $11 \mathrm{H}-5 \mathrm{~W}, 81-83$ & 100.01 & 100.03 & 117.34 & 117.36 & 219.25 & 219.27 & Abundant \\
\hline \multicolumn{8}{|l|}{ 320-U1333C- } \\
\hline $12 \mathrm{H}-4 \mathrm{~W}, 13-15$ & 97.73 & 97.75 & 116.85 & 116.87 & 218.89 & 218.91 & Barren \\
\hline $14 \mathrm{H}-6 \mathrm{~W}, 92-94$ & 116.02 & 116.04 & 137.7 & 137.72 & 244.7 & 244.72 & Abundant \\
\hline $16 \mathrm{H}-1 \mathrm{~W}, 72-73$ & 127.32 & 127.34 & 151.7 & 151.72 & 258.12 & 258.14 & Barren \\
\hline $16 \mathrm{H}-4 \mathrm{~W}, 13-15$ & 131.23 & 131.25 & 155.61 & 155.63 & 261.41 & 261.43 & Barren \\
\hline
\end{tabular}

mbsf $($ CSF-A $)=$ core depth below seafloor, actual length of recovered core, and drillers depth. rmcd (adjusted revised CCSF-A) $=$ shipboard depth scale of the spliced section and correlated depth scale of Site U1333 cores to corrected rmcd of Site 1218 (Westerhold et al., 2012).

Table T2. List of major element composition of glass shards from Sample 320-U1333C-14H-6W, 92-94 cm.

\begin{tabular}{lclc}
\hline Element & Mean (\%) & $\begin{array}{l}\text { Standard } \\
\text { deviation }\end{array}$ & $n$ \\
\hline $\mathrm{SiO}_{2}$ & 73.4 & 0.4 & 181 \\
$\mathrm{TiO}_{2}$ & 0.093 & 0.037 & 181 \\
$\mathrm{Al}_{2} \mathrm{O}_{3}$ & 11.5 & 0.1 & 181 \\
$\mathrm{FeO}$ & 0.66 & 0.09 & 181 \\
$\mathrm{MnO}$ & 0.069 & 0.044 & 181 \\
$\mathrm{MgO}$ & 0.051 & 0.023 & 181 \\
$\mathrm{CaO}$ & 0.40 & 0.07 & 181 \\
$\mathrm{Na} \mathrm{N}_{2} \mathrm{O}$ & 3.02 & 0.20 & 181 \\
$\mathrm{~K}_{2} \mathrm{O}$ & 5.27 & 0.22 & 181 \\
$\mathrm{P}_{2} \mathrm{O}_{5}$ & 0.010 & 0.010 & 181 \\
\cline { 2 - 4 } Total: & 94.5 & 0.5 & 181 \\
\hline
\end{tabular}

